\title{
Regulation of air pollution from wood-burning stoves
}

Bjørner, Thomas B.; Brandt, Jørgen; Gårn Hansen, Lars; Källstrøm, Marianne Nygaard

Published in:

Journal of Environmental Planning and Management

DOI:

10.1080/09640568.2018.1495065

Publication date:

2019

Document version

Early version, also known as pre-print

Citation for published version (APA):

Bjørner, T. B., Brandt, J., Gårn Hansen, L., \& Källstrøm, M. N. (2019). Regulation of air pollution from woodburning stoves. Journal of Environmental Planning and Management, 62(8), 1287-1305.

https://doi.org/10.1080/09640568.2018.1495065 
DEPARTMENT OF FOOD AND RESOURCE ECONOMICS

UNIVERSITY OF COPENHAGEN

\section{IFRO Working Paper}

Regulation of air pollution from wood-burning stoves

Thomas Bue Bjørner Jørgen Brandt Lars Gårn Hansen Martin Groth Hjelms $\varnothing$ Marianne Nygaard Källstrøm 


\section{IFRO Working Paper 2016 / 11}

Regulation of air pollution from wood-burning stoves

Authors: Thomas Bue Bjørner, Jørgen Brandt, Lars Gårn Hansen, Martin Groth Hjelmsø, Marianne Nygaard Källstrøm

JEL Classification: I18, Q48, Q53, Q58

Published: November 2016

See the full series IFRO Working Paper here:

www.ifro.ku.dk/english/publications/foi series/working papers/

Department of Food and Resource Economics (IFRO)

University of Copenhagen

Rolighedsvej 25

DK 1958 Frederiksberg DENMARK

www.ifro.ku.dk/english/ 


\title{
Regulation of air pollution from wood-burning stoves
}

November 2016

\author{
Thomas Bue Bjørner ${ }^{1}$ \\ Jørgen Brandt ${ }^{2}$ \\ Lars Gårn Hansen ${ }^{1,3}$ \\ Martin Groth Hjelms $\emptyset^{1}$ \\ Marianne Nygaard Källstrøm ${ }^{1}$
}

${ }^{1}$ Danish Economic Councils, Amaliegade 44, 1256 Copenhagen K.

${ }^{2}$ Aarhus University, Department of Environmental Science, Frederiksborgvej 399, 4000 Roskilde, Denmark.

${ }^{3}$ University of Copenhagen, Department of Food and Resource Economics, Rolighedsvej 23, 1958 Frederiksberg C, Denmark.

\begin{abstract}
:
Air pollution is a major global challenge. Emissions from residential wood-burning stoves make a surprisingly large contribution to total air pollution related health costs. In Denmark, emissions from wood-burning stoves are calculated to cause almost 400 premature deaths each year within Denmark and additionally about 300 premature deaths in other parts of Europe. In this article, we present an integrated assessment of the net social benefit of different schemes for regulating woodburning stoves including bans and taxes. The assessment uses high resolution air pollution emission inventory, and atmospheric dispersion and exposure models to estimate the health effects of imposing regulations on residential wood-burning. This is combined with an economic stove investment and use model to simulate reactions to regulations and evaluate compliance costs. We find that there are large net welfare gains from most types of regulation, but the largest gains result from imposing a differentiated tax or a general ban on older stoves. The results for Denmark suggest that there could be substantial welfare gains from regulating residential wood-burning stoves in other countries as well.
\end{abstract}

Key words: Wood-burning stoves, particle emission, cost-benefit, regulation, integrated assesment.

JEL codes: I18, Q48, Q53, Q58 


\section{Introduction}

Air pollution causes health problems and loss of life years due to premature death. Calculations of the health costs associated with air pollution for the European Union suggest that these costs are 3-7 per cent of GDP (European Commission, 2013, WHO and OECD, 2015). In Denmark, the annual external health costs resulting from Danish wood-burning stoves has been calculated to be more than half a billion Euros. This is over a third of the Danish health costs caused by air pollution from Danish sources (Brandt et al., 2016, and the Danish Economic Councils, 2016) even though woodburning is only a secondary heating source for the vast majority of Danish homeowners. One reason for this is that there has been little regulatory focus on residential wood-burning stoves, while regulation of, e.g. road traffic, power generation and industrial polluters, has been tightened substantially over recent decades.

The purpose of our study is to investigate the potential welfare benefits of tightening regulations for wood-burning stoves and to investigate the efficient design of such regulations. The results we present for Denmark may have a wider interest since wood-burning stoves, even though they are an important source of air pollution, are largely unregulated in most other countries as well.

There is, of course, substantial literature on modeling particle emissions, dispersion and health effects and on the valuation of these health effects. However, to our knowledge, this study is the first to integrate the modeling of emissions, atmospheric transport and chemical transformation, and the valuation of external costs at a very high resolution $(1 \mathrm{~km} \mathrm{x} 1 \mathrm{~km})$ with an economic model of homeowners' investment in and use of wood-burning stoves. This integration makes it possible for us to simulate the effects of different regulation on the health costs caused by stove users and to estimate the welfare costs inflicted on stove users by these regulations. This ensures that the evaluation of both costs and benefits of a given regulation are conducted in an internally consistent way as are the evaluations across different regulatory schemes. Being the first integrated assessment 
of alternative regulatory schemes in this area, our approach may also have an applied methodological interest.

The integrated modeling framework is used to calculate the costs and benefits of the following types of regulation of air pollution from wood-burning stoves: Total ban on use of all wood-burning stoves, ban on the most polluting stoves and a tax on stove use, which is differentiated according to the emission category of the stove and the geographically distributed external costs of these emissions.

The core of the integrated modelling framework is the health impact assessment model system, EVA (Brandt et al., 2013a;b). The EVA model system is based on the impact pathway methodology and includes the whole chain from emissions, atmospheric chemistry-transport models, human exposure, health impacts and economic valuation of the health impacts. The atmospheric chemistry transport model system consists of a coupling of a regional scale model covering the Northern Hemisphere and a high resolution local scale model covering Denmark, where the contribution of emissions from wood-burning stoves to health impacts can be calculated much more precisely. Basically, the contribution to health impacts depends significantly on the location of the wood stoves with respect to the location, distribution and density of the population - both nearby and further away from the emissions. Therefore, the calculation of the wood-burning stoves contribution to health impacts has been divided into smaller regions of Denmark and as a function of population density. This gives us the foundation for simulating the total costs of particle emission from woodburning stoves and, thereby, the benefits of imposing regulations that reduce emissions.

To simulate how users of wood-burning stoves react to regulations, we specify an economic model of stove investment and use. This model allows us to simulate user reactions to regulations in each locality and, therefore, also to simulate the effects of locally differentiated regulations. The 
economic model also allows us to back out the utility costs for stove users implied by the reactions, which makes it possible to evaluate the net benefits of different regulatory schemes. Finally, the economic model takes into account the differences in administrative costs of the applied regulatory schemes.

We find that most types of regulation of wood-burning stoves yield large social gains. The highest gains are achieved by the differentiated tax on stove use, but a ban on all stoves with emission levels higher than eco-labeled stoves (Nordic Swan eco-label emission standard) also yields a substantial gain. Most of these gains derive from regulation of stoves used in densely populated areas, where the related external health costs are the highest.

In the next section, we describe the integrated modelling framework for calculating the net social benefits of the different types of regulation. Section 3 describes the parameterization of the model and the applied data. The results are presented in section 4, while different sensitivity analyses are described in section 5. The conclusion is presented in section 6 .

\section{Integrated assessment of net social benefits from regulating wood-burning stoves}

Many studies have demonstrated that high concentrations of air pollution and especially fine particles cause negative health effects and increase mortality (See, e.g. Anderson (2015), Dominici et al. (2014) and Pope et al. (2002)). Particles from wood-burning stoves are one of the single largest Danish contributors to air pollution in Denmark estimated to cause almost 400 premature 
deaths and health costs of over half a billion Euros annually (Brandt et al., 2016; Danish Economic Councils, 2016). ${ }^{1}$ Nevertheless, regulation of these emissions is currently limited.

In theory, a Pigouvian tax corresponding to the external costs of particles could internalize the external costs resulting from wood-burning stove. However, this would require measuring the actual emissions of particles from each stove, which would be extremely costly. This may be part of the explanation as to why emissions from wood-burning stoves are generally not regulated. Instead, regulators both in the EU and in the USA have implemented and continually tightened emission standards for producers of new wood-burning stoves. However, the impact of such regulations on emissions is very slow because the typical lifetime of a wood-burning stove is several decades. For example, 37 percent of all wood-burning stoves in Denmark were installed before 2008 (and 17 percent before 1990). To address this problem, authorities in many countries are considering regulating stove use and, e.g. Germany has decided to phase out all stoves produced before 2010 over a 10-year period (Bundesgesetzblatt, 2010).

However, the cost to stove users of using command-and-control regulation, such as bans, may potentially be very high, which is why more flexible types of regulation may be attractive. A tax on firewood has been considered in Denmark, but such a tax would give an incentive to burn nonwood materials, waste, and home-produced firewood of low quality, which may increase pollution. Instead, installing a temperature meter in the flue of each stove has been suggested (The Ecological Council, 2014). This would not measure actual emissions, but would record the number of hours a stove is used, which would make it possible to tax the use of stoves. Such a tax could be differentiated according to local population density and the type of stove so as to reflect more

\footnotetext{
${ }^{1}$ In Europe, emissions of air pollution are typically calculated for 10 different SNAP sectors (Standard Nomenclature for Air Pollution). In Denmark, emissions of primary particles from wood-burning stoves account for 72 percent of all primary particle emissions from SNAP2 (Non-industrial combustion plants, including private wood combustion). The total number of premature deaths in Denmark derived from SNAP2 is 540.
} 
precisely the actual health costs associated with use of the particular stove. The meter installation and administrative costs of such a tax are, on the other hand, substantial.

Thus regulators are faced with a dilemma. They must choose between, on the one hand, second-best tax schemes that may generate reasonably efficient incentives, but with extra administrative costs and, on the other hand, different types of bans that may be easy to implement, but may potentially impose substantially higher compliance costs on stove users. This makes empirical evaluation of the costs and benefits of different schemes the only way to ascertain whether regulation is warranted and which scheme maximizes net social benefits. We do this using an integrated modelling framework consisting of the EVA health impact assessment model system and an economic model of stove investment and use. In the next subsection, we describe the EVA model system that simulates how emissions within a specific geographical grid cell affect monetarized health costs in all grid cells of the model. In the following two subsections, we describe the economic model that simulates stove users' reactions to regulation within each grid cell of the EVA model.

\section{Modelling benefits of reduced emissions from wood-burning stoves}

The EVA (Economic Valuation of Air pollution; Brandt et al., 2013a) model system is based on the impact pathway chain. EVA includes a model of geographical distribution of air pollution emissions (Plejdrup et al., 2011, Plejdrup et al., 2016), a multiscale integrated model system for atmosphere transport and chemistry and a human exposure and health effect model (Brandt et al., 2013a;b; Geels et al., 2015).

The atmospheric models that calculate atmospheric transport and chemistry consist of a combination of a regional scale model and a local scale model. The regional scale model is the Danish Eulerian Hemispheric Model (DEHM), which covers the Northern Hemisphere and includes 
three nested domains over Europe, northern Europe and Denmark with resolutions from $150 \mathrm{~km} \mathrm{x}$ $150 \mathrm{~km}$ for the domain covering the Northern Hemisphere, $50 \mathrm{~km} \times 50 \mathrm{~km}$ for the European domain, $16.7 \mathrm{~km}$ x $16.7 \mathrm{~km}$ for the domain covering Northern Europe and down to $5.6 \mathrm{~km} \times 5.6 \mathrm{~km}$ resolution for the domain covering Denmark (Brandt et al., 2012). The local scale model used is the Urban Background Model (UBM), covering Denmark with a resolution of $1 \mathrm{~km} \mathrm{x} 1 \mathrm{~km}$ (Brandt et al, 2001; 2003). The multiscale integrated model system makes it possible to include the intercontinental and regional transport of air pollution, while maintaining a very high resolution over the area of interest (in this case Denmark). Furthermore, using this approach, geographical distributed changes in human exposure to air pollution resulting from a change in emissions originating from any given area in Europe or Denmark can be calculated. The high resolution model (UBM) is important when calculating the effects of changes in wood-burning stoves because a large proportion of the effects resulting from this emission source are local.

The EVA model system used to calculate health effects is based on exposure-response functions found in the literature based on epidemiological studies and accepted by the World Health Organization (Brandt et al., 2013a). The resulting health effects are then monetarized via unit prizes for each health outcome, e.g. using estimates of the statistical value of lost life years for costs attributed to premature deaths. The EVA system includes 16 different health outcomes and, besides mortality due to short and long term exposure to ozone and atmospheric particles, respectively, the system also includes morbidity such as cardio-vascular or respiratory hospitalizations, restricted activity days, asthma, bronchitis, lung cancer, etc. (see Brandt et al., 2013a for a full list).

In the high resolution modelling at $1 \mathrm{~km} \times 1 \mathrm{~km}$ resolution, the emission data, the air pollution modelling and the population density data are applied in the same grid and at the same high resolution. This allows us to calculate the total costs of emissions from wood-burning stoves depending on the location of the wood stoves with respect to population distribution and, thereby, 
the benefits of imposing regulations that reduce these emissions. In this paper, the calculation of the contribution of wood stoves to health impacts has been divided into 6 regions of Denmark and has been calculated as a function of different population densities in the four intervals $<100,100-1500$, $1500-3000$ and $>3000$ people $/ \mathrm{km}^{2}$.

\section{Modelling private costs and stove users' reactions to regulation}

The amount of particles emitted by wood-burning stoves depends on a number of factors including the type of stove and how much the stove is used, while the geographical location (the grid cell in which the stove is placed) is critical for the health effects these emissions cause. To capture variation in these dimensions, the economic stove investment and use model mirrors the grid specification of the EVA model system. It consists of a number of stove using agents in each geographical grid cell representing variation in preferences for stove use and the type of installed stove. Each of these agents is a specification of an agent model of a stove owner that can be parameterized for different preferences for stove use, and for different initially installed stove types. In this subsection, we explain the workings of this agent model and how it generates reactions to regulation and compliance costs. In the next subsection, we then explain how the economic stove investment and use model for Denmark is constructed using different specifications of the agent model and how this economic model and the EVA model system interact to generate consistent estimates of costs and benefits of regulation.

The integrated model is used to simulate the net social benefits of a differentiated tax on stove use, a ban on the most polluting (old) stoves and a total ban on the use of stoves. Depending on the type of regulation imposed, owners of wood-burning stoves may stop using the stove, reduce use of the stove or replace the stove with a newer one. For a given type of regulation, user reactions are 
modelled in two steps. First, we model the stove owner's investment response, then, conditional on this decision we model the owner's stove use.

To illustrate the agent model, assume that there are only two types of stoves. A new (n) and an old (d), where the old stove pollutes more than the new. Assuming that a tax on stove use is imposed, the owner has the following investment options:

- Buy new stove now: Replace the old stove with a new one just after implementation of the tax

- Stop using stove now: Stop using the stove (without replacing it with a new one)

- Buy new stove later: Keep the old stove for its remaining lifetime; then replace with a new one

- Stop using stove later: Keep the old stove for its remaining lifetime (without replacing it with a new one)

His investment choice is assumed to be the one that yields him the lowest reduction in his consumer surplus. The change in consumer surplus conditional on keeping the old stove and investing in a new stove respectively is illustrated in figure 1 , where the horizontal axes is the use of the stove (number of hours used). Here the demand curve (marginal benefit of user) is named MB. The use of a stove before and after the tax is $\mathrm{Q}_{0}$ and $\mathrm{Q}_{1}$, while $\mathrm{P}_{0}$ and $\mathrm{P}_{1}$ are equal to the private marginal cost of using the stove before and after the tax is imposed ( $t_{d}$ on the old stove and $t_{n}$ on the new stove). New stoves are generally more effective than old stoves, so the private marginal cost of using a new stove is lower than it is for an old stove $\left(\mathrm{MC}_{\text {private, } \mathrm{n}}<\mathrm{MC}_{\text {private, }}\right)$. 
Figure $1 \quad$ Illustration of the effect of a tax on an old and a new wood-burning stove
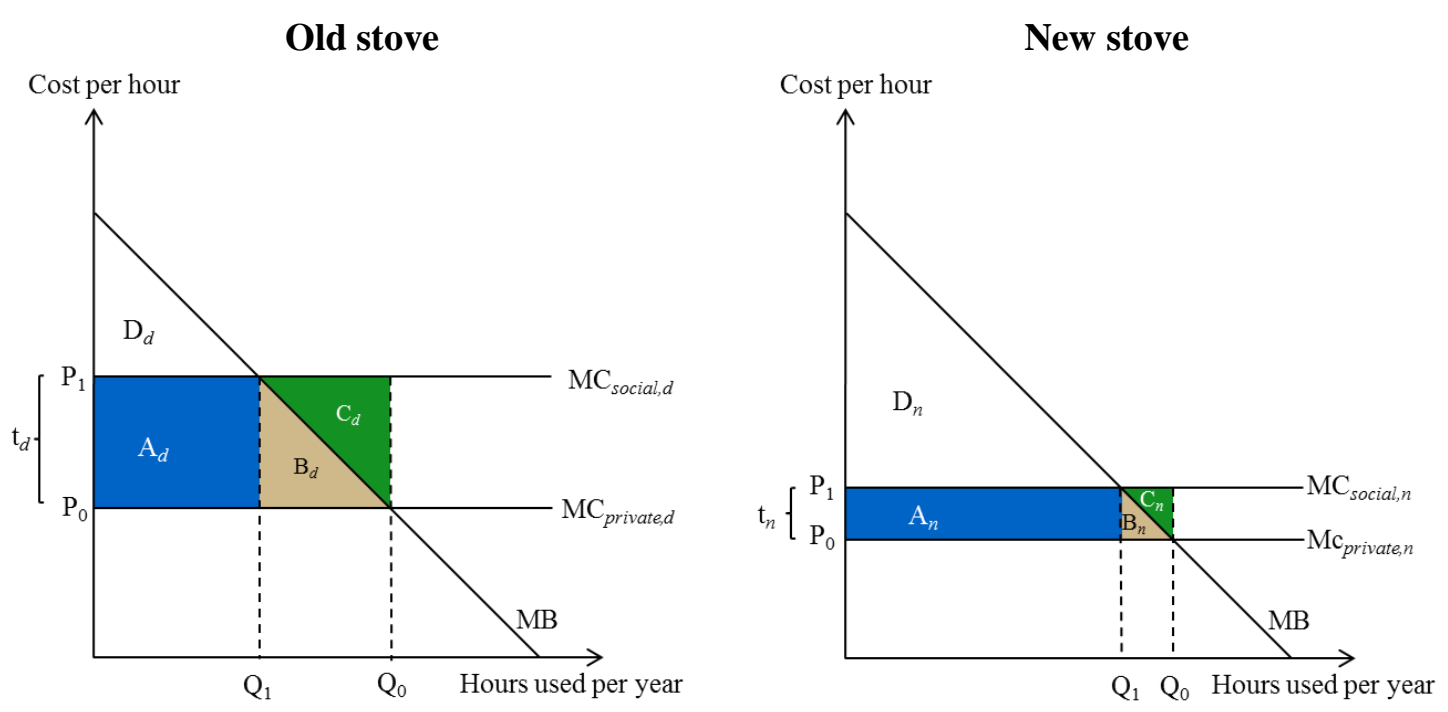

For a user of an old stove, the consumer surplus before the tax is equal to $A_{d}+B_{d}+D_{d}$, because the optimal use level is $\mathrm{Q}_{0}$ and no taxes are paid. After the tax is imposed, the consumer surplus is reduced to $\mathrm{D}_{\mathrm{d}}$ because of tax payment and the reduction in optimal use to $\mathrm{Q}_{1}$. Let us assume that there is a fixed cost $(f)$ associated with the collection of the tax (cost of the meter plus administrative costs) and that the fixed cost is paid by users of stoves. In this case, the consumer surplus after tax is $\mathrm{D}_{\mathrm{d}}-f$. As noted above, the user may also consider buying a new stove instead of keeping the old one, but there is an investment cost $\left(\mathrm{I}_{n}\right)$. If the user chooses to buy a new stove, his consumer surplus (after investment and fixed administrative costs) is $\mathrm{D}_{\mathrm{n}}-f-\mathrm{I}_{\mathrm{n}}$. So the user will buy a new stove if $\mathrm{D}_{\mathrm{n}}-f-\mathrm{I}_{\mathrm{n}}$ is positive and $\mathrm{D}_{\mathrm{n}}-f-\mathrm{I}_{\mathrm{n}}>\mathrm{D}_{\mathrm{d}}-f$. Conditional on the investment decision, optimal use is, as already noted, reduced to $\mathrm{Q}_{1}$ because the tax has increased marginal private use costs. Conditions for other choices by the owner of old stoves subject to a differentiated tax are indicated in the top half of table 3. If the regulator bans old stoves instead of imposing a user tax, the stove owner can either buy a new stove or stop using a stove altogether. However, since stove use is not subject to tax, it is optimal for the owner to set this at $\mathrm{Q}_{0}$ (rather than $\mathrm{Q}_{1}$ ) if he invests in a 
new stove. The resulting conditions which the investment choice options leave open to him under a ban are shown in the lower half table $1 .^{2}$

Table $1 \quad$ Characterization of the choice of owners of old stoves

\begin{tabular}{|l|l|}
\hline Choice & Condition \\
\hline Differentiated tax: & \\
Buy new stove now & $\mathrm{D}_{\mathrm{n}}-f-\mathrm{I}_{\mathrm{n}}>\mathrm{D}_{\mathrm{d}}-f$ and $\mathrm{D}_{\mathrm{n}}-f-\mathrm{I}_{\mathrm{n}}>0$ \\
Stop using stove now & $0>\mathrm{D}_{\mathrm{n}}-f-\mathrm{I}_{\mathrm{n}}$ and $0>\mathrm{D}_{\mathrm{d}}-f$ \\
Buy new stove later $^{a)}$ & $\mathrm{D}_{\mathrm{d}}-f>\mathrm{D}_{\mathrm{n}}-f-\mathrm{I}_{\mathrm{n}}>0$ \\
Stop using stove later & $a)$ \\
\hline Ban on old stoves: & $\mathrm{D}_{\mathrm{d}}-f>0>\mathrm{D}_{\mathrm{n}}-f-\mathrm{I}_{\mathrm{n}}$ \\
Buy new stove now & $\mathrm{D}_{\mathrm{n}}+\mathrm{A}_{\mathrm{n}}+\mathrm{B}_{\mathrm{n}}>\mathrm{I}_{\mathrm{n}}$ \\
Stop using stove now & $\mathrm{D}_{\mathrm{n}}+\mathrm{A}_{\mathrm{n}}+\mathrm{B}_{\mathrm{n}}<\mathrm{I}_{\mathrm{n}}$ \\
\hline
\end{tabular}

Note a): Here it is assumed that the user continues to use the old stove for its remaining lifespan and then either buys a new stove or stops using his wood-burning stove.

\section{Costs and benefits of regulation}

The social welfare effect of regulation depends on the choice made by the owners of stoves. Let us again consider a situation with the use tax where the user has an old stove. If the user of the stove decides to keep his old stove, he will reduce his use from $\mathrm{Q}_{0}$ to $\mathrm{Q}_{1}$ due to the tax $t_{d}$ (see left side of figure 1). For a stove user placed in a specific grid cell, the EVA model then estimates the health benefits (the reduction in health costs) that result from the reduction in emissions that this amount of use reduction for this particular stove type value causes. Assuming the tax rate is set equal to the marginal health costs of stove use (corresponding to the standard Pigouvian recommendation), the welfare gain from reduced air pollution is equal to $B_{d}+C_{d}$. The reduction in consumer surplus due to the tax is $\mathrm{A}_{\mathrm{d}}+\mathrm{B}_{\mathrm{d}}+f$, but $\mathrm{A}_{\mathrm{d}}$ is the tax revenue, which should not be considered a loss from the point of view of society. When the tax revenue is ignored, the social net benefit is $\mathrm{C}_{\mathrm{d}}-f$.

\footnotetext{
${ }^{2}$ Note that with a ban on an old stove instead the user does not have to pay a fixed cost $(f)$ for administrating the tax.
} 
It can be argued that the tax revenue collected through an externality correcting tax provides an additional benefit because it makes it possible to reduce other distortionary taxes (the so-called weak double dividend). The value to society of non-distortionary tax revenue is equal to the marginal costs of public funds $(m)$. If this double dividend is included, the social net benefit becomes $\mathrm{C}_{\mathrm{d}}-f+m \cdot \mathrm{A}_{\mathrm{d}}{ }^{3}$

If the owner of the old stove chooses to stop using his old stove (without replacing it with a new), he experiences a loss in consumer surplus equal to $A_{d}+B_{d}+D_{d}$, but there is also a greater gain due to lower air pollution equal to $A_{d}+B_{d}+C_{d}$. The net benefit is, therefore, equal to $C_{d}-D_{d}$. The social net benefit in the situation where the owner decides to replace the old stove with a new one is calculated in the same way except that the cost of the new stove $\left(\mathrm{I}_{\mathrm{n}}\right)$ has to be deducted.

The social net benefits from a differentiated tax and a ban on old stoves conditional on the choice of the stove owner are summarized in table 2. In the table, we have also included the social net benefit of a ban on all stoves. Here the only option left to the owner is to stop use altogether.

We used figure 1 to illustrate the choice and derived welfare effects of regulation for a given initial use level of an old stove $\left(\mathrm{Q}_{0}\right)$. However, there are substantial differences in preference for stove use across households, which are captured in our model by shifting the demand curve (MB curve) in figure 1, which results in a corresponding shift in initial stove use $Q_{0}$. Clearly both $D_{d}$ and $D_{n}$ are affected and, potentially, so are the investment and use reactions of the stove owners and the social net benefit of the regulation (see table 1 and 2). For example, stove owners are more likely to stop using a stove after a tax has been introduced when their initial use of the stove is low (and therefore $D_{d}$ and $D_{n}$ are small). There are also important differences in the type of old stove that owners have.

\footnotetext{
${ }^{3}$ The marginal cost of public funds is often included in social cost-benefit analyses. However, it has also been argued that the marginal cost of public funds should not be included in such analyses (See, e.g. Kreiner and Verdelin, 2012). Therefore, a sensitivity analysis with $m=0$ is presented in section 5 .
} 
Very old stoves have higher marginal costs of use, which are captured in our agent model by shifting the cost curve up. These stoves also have higher emissions per hour of use, which would imply higher taxes under tax regulation. With these simple parameterizations of the agent model, we are able to capture the key dimensions of variation between stove users.

Table 2 Social net benefit conditional on the choice of the owners of old stoves

\begin{tabular}{|l|l|}
\hline Choice & Social net benefit $^{\text {a) }}$ \\
\hline Differentiated tax: & \\
Buy new stove now & $\mathrm{C}_{\mathrm{d}}-\mathrm{D}_{\mathrm{d}}+\mathrm{D}_{\mathrm{n}}-\mathrm{I}_{\mathrm{n}}-f+m \cdot \mathrm{A}_{\mathrm{n}}$ \\
Stop using stove now & $\mathrm{C}_{\mathrm{d}}-\mathrm{D}_{\mathrm{d}}$ \\
Buy new stove later & $\mathrm{C}_{\mathrm{d}}-f+m \cdot \mathrm{A}_{\mathrm{d}}$ \\
Stop using stove later & $\mathrm{C}_{\mathrm{d}}-f+m \cdot \mathrm{A}_{\mathrm{d}}$ \\
\hline Ban on old stove & \\
Buy new stove now & $\mathrm{C}_{\mathrm{d}}-\mathrm{D}_{\mathrm{d}}+\mathrm{D}_{\mathrm{n}}-\mathrm{C}_{\mathrm{n}}-\mathrm{I}_{\mathrm{n}}$ \\
Stop using stove now & $\mathrm{C}_{\mathrm{d}}-\mathrm{D}_{\mathrm{d}}$ \\
\hline Ban on all stoves: & \\
Stop using stove now & $\mathrm{C}_{\mathrm{d}}-\mathrm{D}_{\mathrm{d}}$ \\
\hline
\end{tabular}

Note a): Note that the social net benefit should be interpreted as short run effects. For example, in the situation with the differentiated use tax, the owner of an old stove may choose to keep the old stove for its remaining life span and after that either buy a new stove ("buy new stove later") or stop using wood-burning stoves altogether ("stop using stove later"). The two situations obviously have different implications for welfare in the long-run.

When simulating, we only take the direct effects from changes in stove use into account. Therefore, we assume that these regulations do not have any indirect effects on health benefits. Such effects could, for example, result if regulations that reduce use wood-burning stoves also induce greater use of other types of heating with which are associated with unregulated external health costs. While regulation of wood burning stoves will probably result in increased use of other types of heating, all the likely substitutes are tightly regulated in Denmark. Although we cannot be certain that these are actually regulated at the optimal level so that there are no remaining indirect external effects, it seems likely that any remaining indirect external effects are small. It is, however, important to stress that if our evaluation framework were to be applied in another setting where important substitute heating sources are not regulated at close to the optimal level, it would be important to take indirect 
external effects through substitution into account. We also assume that there is no second-hand market for wood-burning stoves when simulating. ${ }^{4}$ While this is a reasonable approximation in the Danish context, it may not be the case in other settings.

\section{Model solution, parameterization and data}

In principal, our framework includes agent models that represent stove users covering the relevant span of preference variation and types of old stoves for each grid cell in the EVA system. To facilitate model solution and simulation, all grid cells have been grouped into 24 grid cell types each of which is represented by one set of agent models. Table 5 summarizes the levels/categories of the three dimensions over which our agent models vary.

Table $3 \quad$ Number of levels of external cost, use of stoves and emission categories of the stoves

\begin{tabular}{|c|c|}
\hline External health cost & $\begin{array}{l}\text { Health cost in Denmark of emission of particles in } 24 \text { different emission areas. The } 24 \\
\text { areas are defined using combinations of the } 6 \text { different regions in Denmark and } \\
\text { population density in each region }(0-100,100-1,500,1,500-3,000 \text { and more than } 3,000 \\
\left.\text { inhabitants per } \mathrm{km}^{2}\right) \text {. }\end{array}$ \\
\hline Use of stoves & $\begin{array}{l}\text { First a distinction is made between type of user according to location of dwelling and } \\
\text { dwelling type: } \\
\qquad \quad \text { - Urban user } \\
\quad \text { - } \quad \text { Rural user } \\
\text { - Holiday cottage (also in rural areas) } \\
\text { For each type of user/dwelling, we then distinguish between } 10 \text { different levels of use. } \\
\text { Altogether, this yields } 30 \text { different use levels. }\end{array}$ \\
\hline $\begin{array}{l}\text { Emission categories of } \\
\text { wood-burning stoves }\end{array}$ & $\begin{array}{l}\text { We have data to distinguish between the number and geographical distribution of } 5 \\
\text { categories of wood-burning stove (emission levels described in table 1) } \\
\begin{aligned}- & \text { Before } 1990 \\
- & 1990-2008 \\
- & 2008-2015 \text { (not eco-labeled) }^{\text {a }} \\
\text { - } & \text { Eco-labeled } \\
\text { - } & \text { Eco-labeled }{ }^{\text {a) }} \text { emission standard 2008-2015 standard revised 2015 }\end{aligned}\end{array}$ \\
\hline
\end{tabular}

Notes a): The Nordic Swan ecolabel used in Scandinavia; b): According to the Danish Association of Biomass stoves Industry (DAPO), almost all wood-burning stoves sold from 2015 have emission levels within the levels necessary to obtain the Nordic eco-label. Therefore, there is no category for non-ecolabeled stoves from 2015.

\footnotetext{
${ }^{4}$ In effect we assume that owners who decide to replace an old stove can only choose a new stove with the lowest emission level (eco-label standard revised in 2015). In Denmark, there is an effectively enforced ban on reinstalling old wood-burning stoves and, therefore, the second-hand market for wood-burning stoves can be disregarded.
} 
The EVA model system was run for the year 2013 based on meteorological data and emission data for the same year. Geographically distributed population data were entered for the year 2008 and scaled with the total population between the years 2008 and 2013 to represent the year 2013 . The value of life years lost is based on the value of statistical life - 31 million DKK ${ }^{5}$, which is derived from three Danish studies (Traaholt et al., 2016; Gyrd-Hansen et al., 2016 and Kidholm, 1995).

Emissions from "standard" use of new stoves are considerably lower than for old stoves. For example, emissions from an old stove produced before 1990 are 6 times higher than emissions from a new eco-labelled stove (See table 4). ${ }^{6}$ We use these values as the best available estimate of mean emissions from use of this type of stove in our simulations.

Table $4 \quad$ Emissions for different categories of wood-burning stoves ( $g$ PM 2.5 per GJ)

\begin{tabular}{|l|c|}
\hline Stove year/type & g PM$_{2.5}$ per GJ \\
\hline Before 1990 & 930 \\
\hline 1990-2008 & 740 \\
\hline 2008-2015 (not eco-labeled) & 514 \\
\hline Eco-labeled standard 2008-2015 & 206 \\
\hline Eco-labeled standard revised 2015 & 155 \\
\hline
\end{tabular}

Source: Nielsen et al. (2015) and supplement information from the Danish Centre for Environment and Energy (DCE).

Other core parameters, data and assumptions underlying the simulation model are summarized in table 5. A number of these have a rather weak empirical foundation so we present extensive sensitivity analyses after the results section.

\footnotetext{
${ }^{5}$ This value is considerably higher than the "official" value of a statistical life currently applied in Denmark, but it is close to the results found in the comprehensive meta-analysis of values of statistical life in OECD (2012).

${ }^{6}$ These improvements reflect the fact that new emission regulation standards were adopted in 1990, 2008 and 2015. Note that the quality of wood and the way the stove is used affect emissions. Improper use of the stove may increase emissions substantially above the standard use emission values shown in table 4. However, studies have also shown that there is lower variation in emissions due to incorrect use of a new stove compared to an old stove (Nielsen et al., 2010).
} 
Table $5 \quad$ Overview of central data and parameters in baseline calculations

\begin{tabular}{lll}
\hline Data/parameter & Size & Remarks and Source \\
\hline $\begin{array}{l}\text { Marginal private } \\
\text { cost }\end{array}$ & $\begin{array}{l}\text { EUR 0.45- } \\
0.53 \text { per hour }\end{array}$ & $\begin{array}{l}\text { Cost of firewood per hour depending on the energy } \\
\text { efficiency of each emission category of stove. }\end{array}$ \\
$\begin{array}{l}\text { Distribution of } \\
\begin{array}{l}\text { annual use of wood- } \\
\text { burning stove before } \\
\text { regulation }\left(\mathrm{Q}_{0}\right)\end{array}\end{array} \quad \begin{array}{l}0-3,277 \\
\text { hours per }\end{array}$ & $\begin{array}{l}\text { Two national surveys of the use of wood-burning stoves in } \\
\text { 2011 and 2013 were pooled (Evald, 2012 and Hansen, } \\
\text { 2015). The use of stoves was divided into three dwelling } \\
\text { locations/types: Urban areas, rural areas and holiday } \\
\text { cottages. From the distribution of use for each of these } \\
\text { categories, the average number of hours of use for each } \\
\text { decile was calculated (yielding } 30 \text { use levels altogether). }\end{array}$ \\
\hline
\end{tabular}

Number and 750,000 The aggregate number of stoves and its distribution distribution of wood- stoves in according to the 5 emission categories of stoves, dwelling burning stoves Denmark

Demand curve $\quad-0.0007$

assumed linear with

Same slope assumed for all 30 different initial use levels slope:

$\begin{array}{ll}\text { Annual cost of } & \text { EUR } 67 \text { per } \\ \text { temperature meter }(f) & \text { year }\end{array}$ location (urban, rural and holiday cottages) and the 24 different geographical emission areas (see table 3). Based on the same data sources and assumptions which are applied in the annual emission inventories to UNECE (Nielsen, 2015). (see table 3). The slope parameter corresponds to an average own price elasticity of -0.9 which is found for fire wood in a a Norwegian study (Halvorsen et al., 2010).

Rough estimate of the annualized production costs of a meter and the annual administrative cost associated with collecting the tax (DKK 500 equal to EU 67). Estimate based on information from producers of measurement equipment and cost estimate of administration of electricity meter readings.

Annual cost of new EUR 86 per Based on a cost of $€ 1,300$ for a new stove, which is stove $\left(I_{n}\right) \quad$ year assumed to last 25 years (discount factor of 4 per cent).

Marginal cost of $\quad 0.20$ Recommended value for use in social cost-benefit analysis from the Danish Ministry of Finance.

Note: In general, it is assumed that the size of wood-burning stoves corresponds to a capacity of $5 \mathrm{~kW}$.

The variation in use of wood-burning stoves across Danish households is estimated from two surveys from 2011 and 2013 (Evald, 2012 and Hansen, 2015). The surveys reveal that stoves located in dwellings in rural areas are used more than stoves in dwellings in urban areas or stoves in holiday cottages. The survey data did not indicate any pronounced correlation between the emission 
category of stove and use. Therefore, these dimensions are assumed to be independent in our simulation model.

The demand function is assumed to be linear and parameterized to achieve an own price elasticity of -0.9 for the average use level, which is consistent with a recent empirical study from Norway by Halvorsen et al. (2010). Despite the fact that heating is a necessity good in a cold country like Denmark, a relative high price elasticity is to be expected because close substitutes (electricity, oil, gas, heat pumps and so forth) are readily available in most dwellings in Denmark. Because the shape and slope of the demand curve is critical for our welfare evaluations, we carry out a number of sensitivity analyses with alternative slopes and functional forms.

\section{Results}

An important intermediate result from the EVA model system on which the policy evaluations are based is illustrated in figure 2. This is a map of Denmark where the color of each grid cell covered by the EVA model indicates the calculated health costs of emitting one $\mathrm{kg}$ of particles $\left(\mathrm{PM}_{2.5}\right)$ from that grid cell. Not surprisingly, the health costs of emitting particles are highest in and close to Copenhagen and other large cities in Denmark. 
Figure $2 \quad$ Health cost per $\mathrm{kg}$ emitted $\mathrm{PM}_{2.5}$ according to location of emissions in six regions in Denmark. Each region is divided into four different population densities.

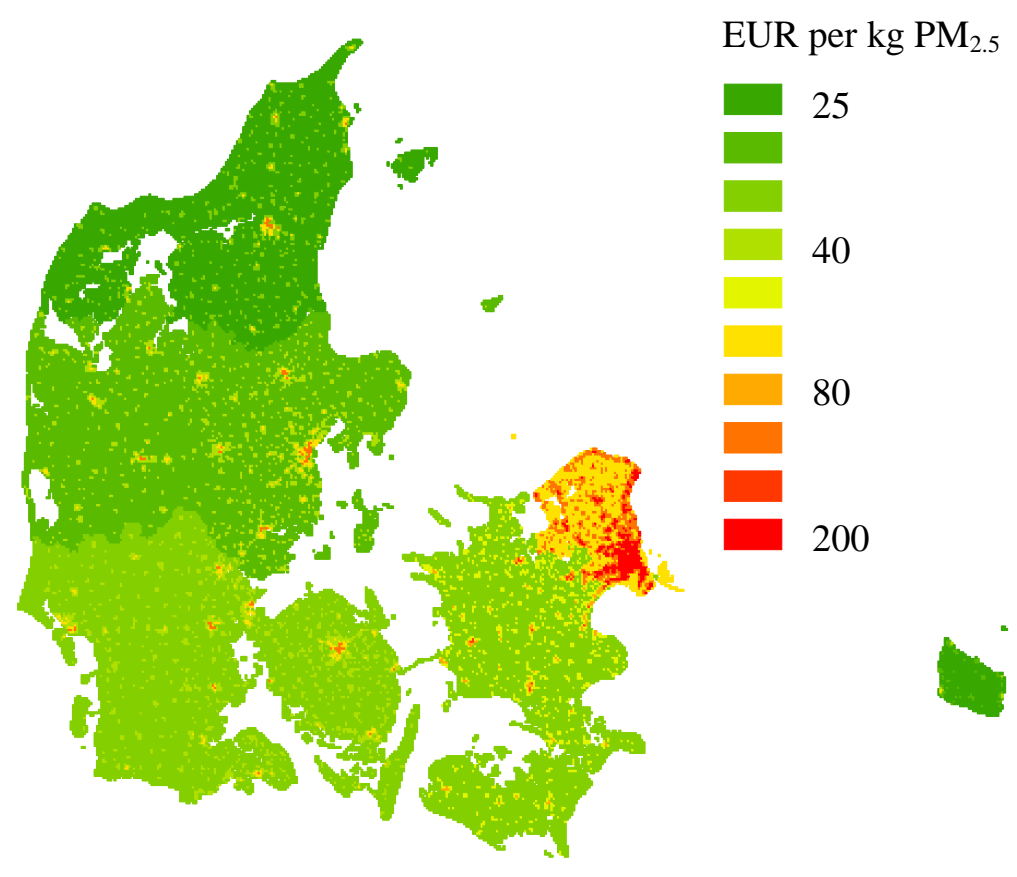

Note: Health costs in Denmark for 24 different areas of emissions. The 24 areas were defined using combinations of 6 different regions in Denmark and the population density in each region (0-100, 100-1,500, 1,500-3,000 and more than 3,000 inhabitants per $\mathrm{km}^{2}$ ). Note that an area according to this definition may consist of a number of unconnected smaller areas within each region. The calculation of the health costs is based on the EVA model (See section 2).

Based on these results, the external health costs that result from the use of different categories of stoves for each of the different areas in figure 2 can be estimated. To illustrate the variation in these costs, table 6 presents the external health costs resulting from one hour of stove use in the areas with the highest and lowest health costs of emissions, respectively, and for the most and least polluting stove categories. There is clearly substantial variation in external costs. It is worth noting that the external costs are substantial and in some areas many times larger than the cost of firewood, which in Denmark is about EUR 0.5 per hour (see table 5). 


\begin{tabular}{lcc}
\hline & Copenhagen $^{\text {a) }}$ & Bornholm $^{\text {a) }}$ \\
\hline & \multicolumn{2}{c}{ EUR per hour use } \\
Stove from before 1990 & 5.5 & 0.7 \\
New eco-labeled stove (revised 2015-standard) & 0.9 & 0.1 \\
\hline
\end{tabular}

Note: Calculated for a stove size corresponding to $5 \mathrm{~kW}$ (a typical stove size in Denmark).

a): The parts of Copenhagen with a population density above 3,000 inhabitants per $\mathrm{km}^{2}$ and the parts of Bornholm with a population density below 100 inhabitants per $\mathrm{km}^{2}$. Bornholm is the island on the far right of of the map in figure 2 .

Before presenting the aggregated welfare effects of imposing various regulations, we present the simulated responses of a few specific stove owner types and the simulated welfare contributions generated by the different regulations. We consider stove owners in two localities (Copenhagen and Bornholm with the highest and lowest external health costs respectively) with two intensities of use (100 and 1,000 hours per year) and with different stove emission categories. Table 7 presents the simulated contribution to annual social net benefits if the indicated regulation was applied to the stove owner. The simulated behavioral response of the stove owner is indicated in brackets. 


\begin{tabular}{|c|c|c|c|c|}
\hline \multirow[b]{2}{*}{$\begin{array}{l}\text { Area and stove } \\
\text { emission category }\end{array}$} & \multirow[b]{2}{*}{$\begin{array}{c}\text { Initial } \\
\text { Consumption }\end{array}$} & \multicolumn{3}{|c|}{ Social net benefit (choice of stove owner) } \\
\hline & & & Tax & Ban on old stoves \\
\hline Copenhagen $^{\text {a) }}$ & Hours per year & ----------. & - & year --------------- \\
\hline Before 1990 & 1,000 & 5.2 & (Stop using) & 4.5 (Buy new) \\
\hline 1990-2008 & 1,000 & 3.6 & (Stop using) & 3.0 (Buy new) \\
\hline $2008-15$ & 1,000 & 2.2 & (Stop using) & 1.6 (Buy new) \\
\hline Nordic eco-label 2008-15 & 1,000 & 0.7 & (Stop using) & 0.0 (Buy new) \\
\hline Before 1990 & 100 & 0.5 & (Stop using) & 0.5 (Stop using) \\
\hline 1990-2008 & 100 & 0.4 & (Stop using) & 0.4 (Stop using) \\
\hline $2008-15$ & 100 & 0.3 & (Stop using) & 0.3 (Stop using) \\
\hline Nordic eco-label 2008-15 & 100 & 0.1 & (Stop using) & 0.1 (Stop using) \\
\hline \multicolumn{5}{|l|}{ Bornholm ${ }^{\text {b) }}$} \\
\hline Before 1990 & 1,000 & 0.5 & (Buy new) & 0.6 (Buy new) \\
\hline 1990-2008 & 1,000 & 0.3 & (Buy new) & 0.4 (Buy new) \\
\hline $2008-15$ & 1,000 & 0.1 & (Buy new) & 0.1 (Buy new) \\
\hline Nordic eco-label 2008-15 & 1,000 & -0.0 & (Keep stove) & -0.1 (Buy new) \\
\hline Before 1990 & 100 & 0.1 & (Stop using) & 0.1 (Stop using) \\
\hline 1990-2008 & 100 & 0.0 & (Stop using) & 0.0 (Stop using) \\
\hline $2008-15$ & 100 & 0.0 & (Stop using) & 0.0 (Stop using) \\
\hline Nordic eco-label 2008-15 & 100 & 0.0 & (Stop using) & 0.0 (Stop using) \\
\hline
\end{tabular}

Note: The table shows examples of the stove owners' choice (in brackets) and the annual social net benefits per regulated stove depending on the type of regulation, stove emission category, geographical location of stove and level of stove use.

a) All parts of Greater Copenhagen, where the population density is above 3.000 per $\mathrm{km}^{2}$ (highest health cost per emitted kg of $\mathrm{PM}_{2.5}$ in Denmark).

b) All parts of the island of Bornholm, where the population density is below 100 per $\mathrm{km}^{2}$ (lowest health costs per emitted $\mathrm{kg}$ of $\mathrm{PM}_{2.5}$ in Denmark).

The results show a larger net social gain of regulation when the stove is old, when it is used in a densely populated area, such as Copenhagen, and when it is used many hours each year. The behavioral differences between regulation schemes can be seen in Copenhagen. A high use stove owner in Copenhagen responds to a ban by buying a new stove, but stops using a stove if a tax is imposed. This is because the tax in Copenhagen is so high that it becomes too expensive to invest in a new stove even though the tax is lower compared to the tax on the old stove. 
To simulate the aggregate welfare effects of regulation, calculations of this type are carried out for all 24 regions and for all 30 use levels of wood-burning stoves and then aggregated. Table 8 presents the aggregated annual social net benefits of the different types of regulations for Denmark. We find a positive social net benefit with all examined types of regulation. The social net benefit is highest with the tax scheme, but a ban on all stoves that do not comply with emission standards for eco-labelled stoves from 2008-2015 is a close runner up. The net gain of both these schemes is approximately EUR 0.4 billion per year. In comparison, the external health costs without regulation are EUR 0.54 billion per year. Only banning the oldest emission category of stoves (from before 1990) yields a substantially smaller social net benefit of about EUR 0.14 billion per year.

Table 8 Aggregated annual net social benefit of different types of regulation

\begin{tabular}{|c|c|c|c|}
\hline & \multirow[t]{2}{*}{ Regulated type of stoves } & \multicolumn{2}{|c|}{ Aggregated annual net social benefit } \\
\hline & & Denmark & Only urban areas \\
\hline & & \multicolumn{2}{|c|}{----------- EUR bn per year ----------- } \\
\hline Tax & All & 0.41 & 0.32 \\
\hline Banning & Before 1990 & 0.14 & 0.11 \\
\hline Banning & Before 2008 & 0.33 & 0.25 \\
\hline Banning & All without nordic eco-label & 0.38 & 0.28 \\
\hline Total ban & All & 0.25 & 0.24 \\
\hline
\end{tabular}

Note: In 2013 prices. Urban areas defined as where population density is above 100 per $\mathrm{km}^{2}$.

If the regulation is only implemented in urban areas where the external costs are generally the highest, the annual net social gain with the tax is EUR 0.32 billion. This illustrates that most of the benefits derive from emission reductions in urban areas.

The impacts of the different regulation schemes on predicted external health costs, premature deaths and the number of wood-burning stoves remaining in service are summarized in table 9 . We find that the number of wood-burning stoves after regulation is lowest when the external costs are internalized with a use tax. 
Table $9 \quad$ Predicted change in number of premature deaths, total health costs and number of wood-burning stoves.

\begin{tabular}{llccc}
\hline & $\begin{array}{l}\text { Stove category } \\
\text { regulated }\end{array}$ & Total health costs & Premature deaths & No. of stoves \\
\hline & & DKK bill. per year & Per year & 1,000 \\
No regulation & & 0.54 & 391 & 750 \\
Tax & All & 0.07 & 54 & 268 \\
Ban of stoves: & Before 1990 & 0.40 & 277 & 688 \\
Ban of stoves: & Before 2008 & 0.20 & 114 & 574 \\
Ban of stoves: & Without eco-label & 0.15 & 70 & 527 \\
Total ban & All & 0 & 0 & 0 \\
\hline
\end{tabular}

Note: In 2013 prices. Lost life years are on average 86 per cent of the total health costs. Each premature death due to air pollution corresponds to around 10 lost life years; see Watkiss et al. (2005) and Brandt et al. (2013a).

\section{Sensitivity analyses and discussion}

In table 10, we present the results of a few key sensitivity variations to indicate the robustness of our welfare ranking of alternative regulatory schemes.

Sensitivity to the assumed slope and shape of the demand curves is illuminated in the first three columns after the baseline results: column 2) the slope is reduced by $50 \%$, column 3) the slope doubled and column 4) a constant own price elasticity functional form is used (at an elasticity equal to -0.9). All have modest impact on the overall welfare effect except in the situation where there is a total ban on the use of all types of wood-burning stoves. The ranking of the other regulation schemes and the overall finding of a substantial welfare gain from regulation is unaffected.

Table $10 \quad$ Sensitivity analyses for aggregated annual net social benefit

\begin{tabular}{|c|c|c|c|c|c|c|c|}
\hline & \multirow[b]{2}{*}{$\begin{array}{l}\text { Stove category } \\
\text { regulated }\end{array}$} & \multicolumn{6}{|c|}{ Aggregated annual net social benefit } \\
\hline & & Base & Half slope & Double slope & $\begin{array}{l}\text { Constant } \\
\text { elasticity }\end{array}$ & $m=0$ & $f=$ EUR 134 \\
\hline & & & & ---- DKK & lions per ye & ----- & ----- \\
\hline Tax & All & 0.41 & 0.44 & 0.39 & 0.41 & 0.40 & 0.39 \\
\hline Ban of: & Before 1990 & 0.14 & 0.15 & 0.14 & 0.14 & 0.14 & 0.14 \\
\hline Ban of: & Before 2008 & 0.33 & 0.34 & 0.33 & 0.32 & 0.33 & 0.33 \\
\hline Ban of: & No eco-label & 0.38 & 0.38 & 0.37 & 0.36 & 0.38 & 0.38 \\
\hline Total ban & All stoves & 0.25 & 0.40 & -0.05 & 0.38 & 0.25 & 0.25 \\
\hline
\end{tabular}


The last two columns illustrate the importance of the assumed marginal cost of public funds and the assumed administrative costs of tax collection. Both of these could be critical for our baseline finding that the largest gain from regulation is achieved through a tax scheme. In column 5, we set the double dividend benefit from collecting tax revenue to zero $(m=0){ }^{7}$ In column 6 , the fixed cost of collecting the tax on stove use is doubled ( $\mathrm{f}=134)$. Again the ranking of regulation schemes and the overall finding of a substantial welfare gain from regulation is unaffected. ${ }^{8}$ It is, however, notable that the general ban on non-ecolabeled stoves achieves a welfare benefit of over $90 \%$ of that achieved by the tax scheme in all alternatives.

When evaluating the scale of the calculated benefits from regulation, it is important to stress that while we include the external costs of particle emissions in health costs, particles also have negative effects on the environment, which are not included. For example, black carbon components of particles increase global warming. Furthermore, the calculations only included health impacts from emissions of primary particles and the formation of secondary inorganic particles (nitrate, sulfate and ammonium particles) from emissions of the gases nitrogen-oxides $\left(\mathrm{NO}_{\mathrm{x}}\right)$ and sulphur-dioxide $\left(\mathrm{SO}_{2}\right)$. The formation of secondary organic aerosols from emissions of volatile organic compounds was not included since knowledge is presently lacking on the formation rates of the secondary organic particles. This suggests that the benefits of regulation are higher than indicated in our calculations.

\footnotetext{
${ }^{7}$ Some studies have suggested that the marginal cost of public funds should not be included in social cost benefit analysis, see e.g. Kreiner and Verdelin (2012).

${ }^{8}$ We have conducted a number of other sensitivity analyses including variation of the external health cost and the cost of buying a new wood-burning stove $\left(\mathrm{I}_{\mathrm{n}}\right)$, all of which indicate substantial gains from regulation and that either taxes or in a few cases the ban on non-ecolabeled stoves maximizes this benefit.
} 


\section{Summary and conclusion}

Air pollution causes severe effects on human health and related societal costs. Residential woodburning stoves result in emissions which make a surprisingly large contribution to total air pollution related health costs. In this article, we present the results from an integrated assessment of the net social benefit of different schemes for regulating wood-burning stoves. We find that there are large net welfare gains from most types of regulation, but the largest gains result when from imposing a differentiated tax or a general ban on non-ecolabeled stoves. The gains mainly derive from the regulation of wood-burning stoves located in urban areas. The results for Denmark, where these emissions currently are largely unregulated, suggest that there could be substantial welfare gains from regulating residential wood-burning stoves in other countries as well.

Our results are based on a high resolution air pollution emission inventory and an atmospheric dispersion and exposure model combined with an economic model that takes location, stove type and variation in preferences into account when simulating both stove investment and use behaviour. While baseline uncertainty is substantial, our integrated assessment model allows us to investigate the sensitivity of rankings to key parameter assumptions. Our sensitivity analyses suggest that these ranking results are robust. Furthermore, there are environmental and secondary aerosol health benefits from reducing use of wood-burning stoves that are not captured by our model. This suggests that the simulated welfare benefits from introducing the regulation schemes we investigate underestimate the true benefits.

\section{Acknowledgements}

We would like to thank DCE (National Centre for Environment and Energy with the project: Health impacts and external costs from air pollution in Denmark over 25 years), and NordForsk (under the Nordic Programme on Health and Welfare. Project \#75007: Understanding the link between air pollution and the distribution of related health impacts and welfare in the Nordic countries (http://NordicWelfAir.au.dk)) for supporting the development of the high-resolution modelling of air pollution and health impacts. 


\section{References}

Anderson, M. (2015): As the Wind Blows: The Effects of Long-Term Exposure to Air Pollution on Mortality. NBER Working Paper No. 21578. National Bureau of Economic Research.

Brandt, J., J. H. Christensen, L. M. Frohn, F. Palmgren, R. Berkowicz and Z. Zlatev (2001). Operational air pollution forecasts from European to local scale. Atmospheric Environment, Vol. 35, Sup. No. 1, pp. S91-S98, 2001

Brandt, J., J. H. Christensen, L. M. Frohn and R Berkowicz (2003). Air pollution forecasting from regional to urban street scale - implementation and validation for two cities in Denmark. Physics and Chemistry of the Earth, Vol. 28, pp. 335-344, 2003.

Brandt, J., Silver, J.D., Frohn, L., Geels, C., Gross, A., Hansen, A.B., Hansen, K.M., Hedegaard, G.B, Skjøth, C. A., Villadsen, H., Zare, A. and Christensen, J., H. (2012): An integrated model study for Europe and North America using the Danish Eulerian Hemispheric Model with focus on intercontinental transport. Atmospheric Environment, Volume 53, June 2012, pp, 156-176, doi:10,1016/j,atmosenv,2012,01,011

Brandt, J., Silver, J.D., Christensen, J.H., Andersen, M.S., Bønløkke, J. , Sigsgaard, T., Geels, C., Gross, A., Hansen, A.B., Hansen, K.M., Hedegaard, G.B, Kaas, E. and Frohn, L.M. (2013a): Contribution from the ten major emission sectors in Europe to the Health-Cost Externalities of Air Pollution using the EVA Model System - an integrated modelling approach, Atmospheric Chemistry and Physics, Vol. 13, pp. 7725-7746, 2013, doi:10,5194/acp-13-7725-2013.

Brandt, J., J. D. Silver, J. H. Christensen, M. S. Andersen, J. Bønløkke, T. Sigsgaard, C. Geels, A. Gross, A. B. Hansen, K. M. Hansen, G. B. Hedegaard, E. Kaas and L. M. Frohn, (2013b). Assessment of Past, Present and Future Health-Cost Externalities of Air Pollution in Europe and the contribution from international ship traffic using the EVA Model System. Atmospheric Chemistry and Physics. Vol. 13, pp. 7747-7764, 2013. doi:10.5194/acp-13-7747-2013.

Brandt, J., S.S. Jensen, M.S. Andersen, M. Plejdrup and O.K. Nielsen (2016): Helbredseffekter og helbredsomkostninger fra emissionssektorer $i$ Danmark. Videnskabelig rapport fra DCE - Nationalt Center for Miljø og Energi nr. 182. Institut for Miljøvidenskab, Aarhus Universitet.

European Commission (2013). Impact Assessment. Commission Staff Working Document. SWD(2013) 531 final, Brussels.

Bundesgesetzblatt (2010). Erste Verordnung zur Durchführung des BundesImmissionsschutzgesetzes (Verordnun über kleine und mittlere Feuerungsanlagen - 1. BlmSchV) from the 26th of January 2010. Tell I Nr. 4, ausgegeben zu Bonn am 1. Februar 2010.

The Ecological Council (2014): Partikelforureningsafgift på brandefyring. Copenhagen 11.02.2014. The Ecological Council.

Danish Economic Councils (2016). Økonomi og Miljø - 2016 (Economy and Environment - 2016). Economy. Secretariat of the Danish Economic Councils, Copenhagen. 
Dominici, F., M. Greenstone and C.R. Sunstein (2014): Particulate Matter Matters. Science, 344, p. 257-259.

Evald, A. (2012): Brændeforbrug i Danmark 2011 Energistyrelsen. FORCE Technology, Afdeling for Biomasse \& Affald.

Geels, C., C. Andersson, O. Hänninen, A. S. Lansø, P. Schwarze and J. Brandt (2015). Future Premature Mortality due to Air Pollution in Europe - Sensitivity to Changes in Climate, Anthropogenic Emissions, Population and Building stock, Int. J. Environ. Res. Public Health, Int. 2015, 12, 2837-2869. doi:10.3390/ijerph120302837.

Gyrd-Hansen, D., Kjær, T. and Nielsen, J.S. (2016): The value of mortality risk reductions. Pure altruism - a confounder. Journal of Health Economics, 49, p. 184-192.

Halvorsen, B., B. Larsen and R. Nesbakken (2010): Is There a Win-Win Situation in Household Energy Policy? Environmental and Resource Economics, 45 (4), p. 445-457.

Hansen, M.T. (2015): Brændeforbrug i Danmark 2013. Energistyrelsen. Force Technology, Termisk Energi og Strømningsmekanik.

Kidholm, K. (1995): Estimation af betalingsvilje for forebyggelse af personskader ved trafikulykker. Center for Helsetjenesteforskning og Socialpolitik, Odense Universitet.

Nielsen, O. K.; M. S. Plejdrup, M. Winther, M. H. Mikkelsen, M. Nielsen, S. Gyldenkærne, P. Fauser, R. Albrektsen, K. Hjelgaard, H. G. Bruun and M. Thomsen (2015). Annual Danish Informative Inventory Report to UNECE. Emission inventories from the base year of the protocols to year 2013. Scientific report from DCE - Danish Centre for Environment and Energy (no. 145). Aarhus University, Department of Environmental Science.

Nielsen, O.K., J.B. Illerup, K. Kindbom, K. Saarinen, K. Aasested, B. Hallsdottir, M. Winther, Å. Sjodin, K. Makela and J. Mikkola-Pusa (2010): Review, Improvement and Harmonisation of the Nordic Particulate Matter Air Emissions Inventories, Teknisk rapport nr. 809. DCE - Danish Centre for Environment and Energy. Aarhus University, Department of Environmental Science.

OECD (2012). Mortality risk Valuation in Environment, Health and Transport Policies.

Plejdrup, M.S., Gyldenkærne, S., 2011. Spatial Distribution of Emissions to Air - the SPREAD Model. National Environmental Research Institute, Aarhus University, Denmark, p. 72. NERI Technical Report no. FR823.

Plejdrup, M. S., O.-K. Nielsen and J. Brandt, 2016. High resolution gridding of emissions from residential wood combustion in Denmark. Atmospheric Environment, Vol. 144, November 2016, Pages 389-396. 
Pope, C.A.; R.T. Burnet, M.J. Thun, E.E. Calle, D. Krewski, K. Ito and G.D. Thurston (2002): Lung Cancer, Cardiopilmonary Mortality, and Long-term Exposure to Fine Particulate Air Pollution. The Journal of the American Medical Association, 287 (9), p. 1132-1141.

Kreiner, C.T. and N. Verdelin (2012). Optimal Provision of Public Goods: A Synthesis. Scandinavian Journal of Economics, 114 (2), p. 384-408.

Traaholt, N.V., M.H. Kjeldsen and S. Navrud (2016). Betinget vardisatning af vardien af statistisk liv i Danmark. Working paper 2016:1. The Secretariat of the Danish Economic Councils.

Watkiss, P., S. Pye and M. Holland (2005): CAFE CBA: Baseline Analysis 2000 to 2020. Service Contract for Carrying out Cost-Benefit Analysis of Air Quality Related Issues, in particular in the Clean Air for Europe (CAFE) Programme.

WHO and OECD (2015). Economic cost of the health impact of air pollution in Europe: Clean air, health and wealth. Copenhagen: WHO Regional Office for Europe. 